\title{
SHELF LIFE EVALUATION OF BUFFALO SAUSAGES SUPPLEMENTED WITH DIFFERENT FAT SOURCES AND STORAGE CONDITIONS
}

\author{
K. Nauman ${ }^{1 *}$, M. T. Akbar ${ }^{1}$, M. H. Jaspal ${ }^{1}$, S. Ali ${ }^{1}$, J. Nasir ${ }^{1}$, B. Asghar ${ }^{1}$ and S. Mehmood ${ }^{2}$ \\ ${ }^{1}$ Department of Meat Science and Technology; ${ }^{2}$ Department of Poultry Production, Faculty of Animal Production and \\ Technology, University of Veterinary and Animal Sciences, Lahore 54000, Pakistan \\ *Corresponding author's: drkashif@uvas.edu.pk
}

\begin{abstract}
The study was undertaken to evaluate supplementation of different fat sources (buffalo kidney, pelvic, heart (KPH) fat, sheep tail fat, palm kernel butterfat) on shelf life parameters (thiobarbituric acid values (TBARs), total viable count (TVC), water activity $\left(\mathrm{a}_{\mathrm{w}}\right)$ and color values) in sausages of buffalo calves at different storage temperature and storage duration. Sausages were prepared by employing the hurdle technology that includes mixing of minced buffalo meat and $20 \%$ fat with spice mixture, ascorbic acid, $0.5 \%$ Nitrite- $\mathrm{NaCl}$, phosphate, $5 \%$ potassium ascorbate spray. Sausages were stored at refrigerated $\left(2 \pm 2{ }^{\circ} \mathrm{C}\right)$ and in an incubator to mimic high ambient temperature $\left(35 \pm 2{ }^{\circ} \mathrm{C}\right)$ until 11 days or acceptable limits. The data were analyzed through factorial ANOVA. Results show that hurdle treatment collectively increased the shelf life by significantly reducing quality deterioration during storage. Lowest color lightness ( $\mathrm{L}^{*}$ ) values were recorded in animal-based fat sausages, while the redness $\left(\mathrm{a}^{*}\right)$ values were increased during the storage, and maximum values were observed during storage at ambient temperature. Sheep tail fat sausages exhibited the highest TBARs and TVC values. Similarly, storage temperature and duration affected the quality characteristics, samples stored at an ambient temperature markedly increased the TBARS, TVC and color throughout the storage duration, whereas Aw value decreased. Palm kernel butterfat (PKBF) sausages show higher lightness $\left(\mathrm{L}^{*}\right)$ and yellowness $\left(\mathrm{b}^{*}\right)$ values and lower redness $\left(\mathrm{a}^{*}\right)$ values than buffalo kidney, pelvic, heart (KPH) fat and sheep tail fat (STF) sausages. PKBF sausages showed lowest TVC values represented in terms of $\log \mathrm{cfu} / \mathrm{g}$ while the highest values were observed in STF sausages; however, KPH sausages showed mediate values. Based on these results, it was concluded that sausages made from palm kernel butter fat showed the highest shelf life as compared to the animal source fat sources.
\end{abstract}

Keywords: kidney pelvic heart fat, sheep tail fat, palm kernel butterfat, beef sausages, shelf stability.

https://doi.org/10.36899/JAPS.2020.4.0096

Published online April 25, 2020

\section{INTRODUCTION}

Meat and meat products are important sources of high-quality protein (Górska-Warsewicz et al. 2018). Consumers demand meat and meat products that have a healthy percentage of constituents and satisfy organoleptic expectations (Lorenzo et al. 2013). Ready to cook and ready to eat products share is getting bigger and bigger due to urbanization, more disposable money, improving living standards and busy life routines have changed eating habits of the majority of the population particularly in urban areas of the country (Nauman et al. 2016)

Consumers expectations about safe and nutritious products may be tarnished due to certain factors including biological hazards, lipid and protein oxidation which disturb the nutritional and sensory quality of meat product (Qi et al. 2015). The occurrence of pathogenic bacteria causing spoilage of food is a worldwide growing issue resulting in meat quality and safety issues today. A small number of pathogenic microorganisms are generally required to initiate growth and contamination, introducing significant meat safety risks in the processing industry (Brooks and Flint, 2008). Oxidation is another major factor, which may reduce the quality of meat and meat products by reacting with lipids and proteins, which are responsible for the nutritional, texture, and sensory changes in food products (Ladikos and Lougovois, 1990; Mielnik et al. 2006).

To increase the shelf life of meat products many techniques like thermal processing in a sealed container or by adjusting hurdles such as $\mathrm{pH}$, water activity $\left(\mathrm{a}_{\mathrm{w}}\right)$, food preservatives (Kanatt et al. 2002) or irradiation (Leistner, 2000) can be applied on the food products to store them with/without refrigeration (Thakur and Saxena, 2000). The main objective is to inhibit the growth of microbes, production of their hazardous products and oxidative derivatives in the food, while many other measures are also adopted to maintain good sensory qualities along with the stability of the product as well as saving on energy and money (Leistner and Gorris, 1995; Karthikeyan et al. 2000; Das and Radhakrishna, 2001).

The arcade of the snack food industry mostly includes semi-processed, cooked and ready to eat foods. One of the most common snack foods consumed around 
the world is sausages. Sausages are versatile and popular products with good acceptability (Yang et al. 2007). Sausages are quite famous in developed countries, but in developing countries like Pakistan, it is still considered as an exotic product, neglected and required further investigation and development according to local taste adoption.

Buffalo meat has more premium characteristics due to its flavor, low-fat contents, less cholesterol and muscle $\mathrm{pH}$, milky white nature of its fat and rich in protein in comparison to cow meat (Valin et al. 1984). Even with this enriched comparative edge, value addition and product development potential of buffalo meat are unexplored (Borghese, 2005), either the chilled meat is exported, or meat is utilized in traditional curry, and stew meat dished.

The present study was designed to determine the suitability of buffalo meat for the development of sausages, evaluation of its shelf life stability and microbial safety using three different fat sources, stored at different temperatures and durations.

\section{MATERIALS AND METHODS}

Procurement of raw material: Raw meat and kidney, pelvic and heart (KPH) fat were obtained from the Department of Meat Science and Technology. Animals were slaughtered according to Pakistan Halal Standards (PS 3733:2016). Sheep tail fat obtained from the local slaughterhouse and palm kernel butterfat was purchased from the food ingredient market in Lahore, Pakistan. The spice mixture was procured from Gewuerzmueller, (FRUTAROM Savory Solutions GmbH, Siemensstraße 1, Korntal-Münchingen, Germany), while $32 \mathrm{~mm}$ nonedible collagen casings were purchased from Shenguan (Wuzhou, Guangxi, China).

Ascorbic acid (Vit.C), Nitrite-NaCl were obtained from Merck (Darmstadt, Germany) and Sodium phosphate was obtained from Sigma Aldrich (Gillingham-Dorset, England). All chemicals and reagents used in this study were of analytical grade.

Carcasses were chilled for $24 \mathrm{~h}$ at $4{ }^{\circ} \mathrm{C}$, then meat cubes of about $3 \mathrm{~cm}^{3}$ were obtained from deep $M$. pectoral (brisket region).

Preparation of sausage: Buffalo meat cubes were minced by $13 \mathrm{~mm}$, followed by $8 \mathrm{~mm}$ plates of meat mincer (Dynasty, Model No. HL-G22S, Taiwan). Similarly, buffalo KPH fat and sheep tail fat were minced by $13 \mathrm{~mm}$ and then $3 \mathrm{~mm}$ plates of the same mincer. The sausage recipe was as follows: buffalo meat $2000 \mathrm{~g}$, palm kernel butterfat (PKBF) or buffalo kidney, pelvic, heart fat $(\mathrm{KPH})$ or sheep tail fat $(\mathrm{STF}) 320 \mathrm{~g}$, spice mixture $18 \mathrm{~g}$, ascorbic acid $1.5 \mathrm{~g}$, Nitrite- $\mathrm{NaCl} 0.5 \% 70 \mathrm{~g}$, phosphate $10 \mathrm{~g}$. All the ingredients were added in the mixer (CEMM 30, Omega Group, Italy) to prepare emulsion during mixing. Mince was cooled at $4^{\circ} \mathrm{C}$ for about 2 hours to provide curing time. Mince was transferred to bowl chopper (DMS-Machine system, DMK 20, Germany) for homogenization. Meat batter was stuffed using $32 \mathrm{~mm}$ collagen casings using vacuum sausage stuffer (DMS-Machine system, DF 250, Germany) and linked manually at about $9 \mathrm{~cm}$ intervals, cooked in a hot air oven at $85^{\circ} \mathrm{C}$ to attain internal core temperature of $75+{ }^{\circ} \mathrm{C}$ to maximize food safety aspect of a product (Seo et al. 2016). Sausages were sprayed with a $5 \%$ potassium sorbate solution and then allowed to dry out at room temperature for 15 minutes to limit the growth of mold and fungal (Thomas et al. 2008). The same procedure was followed, and three separate batches were prepared respectively manifesting each fat type (buffalo KPH (kidney, pelvic, heart) / Sheep tail/palm kernel butterfat). Subsequently, half of the samples from each batch were placed in the incubator to mimic high ambient temperature at $35 \pm 2{ }^{\circ} \mathrm{C}$ while remaining samples were placed in the chiller to maintain chilling temperature $2 \pm 2^{\circ} \mathrm{C}$. On $1^{\text {st }}, 3^{\text {rd }}, 5^{\text {th }}, 7^{\text {th }}, 9^{\text {th }}$ and $11^{\text {th }}$ day following quality parameters were evaluated.

\section{Sausages quality evaluation}

Color determination: For measurement of color, the sausages were cut longitudinally and colorimeter (Konica Minolta ${ }^{\circledR}$ CR-410, Japan) with $50 \mathrm{~mm}$ port size, D65 illuminant, was placed on the center of the samples. The calorimeter was calibrated each time before recording the observations with provided white calibration plate No. 15533024 for CR-410 with $2^{\circ}$ OBSERVER was used. Calibration values were $\mathrm{Y}=85.40, \mathrm{x}=.3178, \mathrm{y}=.3338$. Samples were sliced and wrapped in a single layer of cling film in a way that uniform bubble-free surface obtained. Observations were recorded from three samples per treatment selected randomly. The color of both chilled and incubator stored sausage samples were measured on $1^{\text {st }}, 3^{\text {rd, }} 5^{\text {th }}, 7^{\text {th }}, 9^{\text {th }}$ and $11^{\text {th }}$ day, and expressed by lightness $\left(\mathrm{L}^{*}\right)$, redness $\left(\mathrm{a}^{*}\right)$, yellowness $\left(\mathrm{b}^{*}\right)$, Chroma (c) and Hue (h) values.

Water activity: Water activity $\left(a_{\mathrm{w}}\right)$ was measured by following the protocol of (Thomas et al. 2008), by using water activity meter (benchtop Aqualab 4TE, Decagon, USA). About $2 \mathrm{~g}$ grounded sample from each treatment was placed inside the water activity meter, and readings were noticed after meter showed the stable sign. Observations were recorded for both stored samples on the $1^{\text {st }}, 3^{\text {rd, }} 5^{\text {th }}, 7^{\text {th }}, 9^{\text {th }}$ and $11^{\text {th }}$ day of storage; an average of three readings was considered the final value.

Lipid oxidation analysis: Readings were obtained on the $1^{\text {st }}, 3^{\text {rd }} 5^{\text {th }}, 7^{\text {th }}, 9^{\text {th }}$ and $11^{\text {th }}$ day of trial by using a 2 -TBA reactive substances (TBARS) method. About 2 grams of each sample was weighed and poured into a $50 \mathrm{ml}$ falcon tube. Fifty $\mu \mathrm{L}$ of butylated hydroxytoluene (7.2\%) was added into the tube along with $15 \mathrm{ml}$ of double-distilled 
water and then homogenized using a Polytron homogenizer (type PT 10/35, Brinkman Instruments Inc. USA). When the sample was homogenized, then $1 \mathrm{ml}$ of sausage sample homogenate was transferred to a disposable test tube $(13 \times 100 \mathrm{~mm})$ along with the $2 \mathrm{ml}$ solution mixture of TBA/TCA. The mixture was then mixed thoroughly using a vortex. After these tubes were incubated in a boiling water bath operating at $90^{\circ} \mathrm{C}$ for 15 min to develop color. Then samples were allowed to cool down in ice water for $10 \mathrm{~min}$. Test tubes were vortex mixed again and then centrifuged for $15 \mathrm{~min}$ at $2000 \mathrm{rpm}$ at $4^{\circ} \mathrm{C}$ (Ohkawa et al. 1979). The absorbance of the resulting supernatant solution was determined at $531 \mathrm{~nm}$ in a spectrophotometer against a blank containing $1 \mathrm{ml}$ of deionized distilled water and $2 \mathrm{ml}$ of TBA/TCA solution. TBARS was calculated from a standard calibration curve prepared using 1, 1, 3, 3-tetra ethoxy propane. The values of TBARS were expressed as milligrams of malondialdehyde per kilogram of meat (mg MDA/ $\mathrm{kg}$ ). The calculation was made as:

TBARS value $(\mathrm{mg} \mathrm{MDA} / \mathrm{kg}$ of meat $)=4 \times$ absorbance at $531 \mathrm{~nm}$.

Total Viable Count (TVC): TVC was performed by following the procedure of Ahmad and Srivastava, (2007) with minor modifications. After the casing is peeled, $10 \mathrm{~g}$ sample was aseptically collected and homogenized in a stomacher (BagMixer 400, Interscience, St. Nom, France) with $90 \mathrm{ml}$ sterilized peptone water for $3 \mathrm{~min}$ at medium paddling speed. Subsequently, 10 fold serial dilutions of $10^{-2}, 10^{-3}, 10^{-4}$ and $10^{-5}$ were prepared by transferring 1 $\mathrm{ml}$ of the previous dilution into the $9 \mathrm{ml}$ of next diluent. All dilutions were manually shaken for 12 seconds. Finally, samples were poured into Petri dishes containing nutrient agar medium with the help of micropipette using different tips for each dilution (APHA, 1992) and spreaded with the help of glass spreader which was dipped in an alcohol solution and flamed on a spirit lamp before use. After that Petri plates were inverted and promptly placed in an incubator for 48 hours at $35^{\circ} \mathrm{C}$. Plates of each dilution having 30-300 colonies were counted. CFU per gram was calculated by dividing the number of colonies over volume used in $\mathrm{ml}$ and multiplying with the dilution factor.

Statistical analysis: The data were analyzed through factorial ANOVA, assuming fat source as main effect and storage temperature and duration as sub-effects and their interaction was also checked. PROC GLM was employed in SAS software (Version, 9.1). Significantly different treatment means were separated through Duncan's Multiple Range test $(P \leq 0.05)$.

\section{RESULTS AND DISCUSSION}

Color: Palm kernel butterfat (PKBF) sausages showed higher lightness $\left(\mathrm{L}^{*}\right)$ and yellowness $\left(\mathrm{b}^{*}\right)$ values and lower redness $\left(\mathrm{a}^{*}\right)$ values than buffalo kidney, pelvic, heart fat (KPH) and sheep tail fat (STF) sausages, as shown in Table (1).

Similar findings were described by Dzudie et al. (2005), who reported higher $L^{*}$ values of hydrogenated sunflower oil sausages than pork, beef, and mutton fat sausages. Incorporation of pre-emulsified plant oil in formulation increased lightness and decreased the redness values causing color change (Cáceres et al. 2008). This might be attributed to the degree of fat dispersion in sausages. The fat present in PKBF sausages could be more finely broken up than sausages utilizing animal fats, thus imparting a more significant impression of lightness. Likewise, higher $\mathrm{L}^{*}$ values were observed in the case of chicken frankfurters formulated with palm oil (Tan et al. 2001).

Irrespective of the treatments, $\mathrm{L}^{*}$ and $\mathrm{b}^{*}$ instrumentally decreased; however, $\mathrm{a}^{*}$ and chroma $(\mathrm{C})$ values were slightly increased at the end of the experiment. Findings of the present study are in accordance with (Cavalheiro et al. 2013) who pointed out that $a^{*}$ values were increased whereas $b^{*}$ values were decreased during the observation period. Reduced $b^{*}$ values were probably due to oxygen consumption by microorganisms, enzymes and decreased oxymyoglobin contents.

Furthermore, samples placed at $35 \pm 2{ }^{\circ} \mathrm{C}$ showed higher $\mathrm{a}^{*}$ but lower $\mathrm{L}^{*}$ and $\mathrm{b}^{*}$ values than the samples stored at $2^{\circ} \mathrm{C}$. Kamenik et al. (2012) found that sausages stored at $15^{\circ} \mathrm{C}$ temperature had a higher proportion of red color whilst the lower proportion of yellow color in comparison to the sausages stored at $5^{\circ} \mathrm{C}$. Results demonstrated that with the advancement in the storage period, a darker color was noted. A similar observation was made by Kamenik et al. (2012) who determined that sausages darken in the course of maturing process; a fall in $L^{*}$ and $b^{*}$ values were observed during storage whereas $\mathrm{a}^{*}$ value increased significantly in KPH sausages at $11^{\text {th }}$ day of storage placed at $35^{\circ} \mathrm{C}$. Similarly, Guo et al. (2003) investigated the color stability of Chinese sausages and reported that the $\mathrm{L}^{*}$ and $\mathrm{b}^{*}$ values of all sausages decreased, but the $\mathrm{a}^{*}$ values increased with progress in storage time. Furthermore, it was determined that the main factor affecting color development and stability was not only processing temperature but storage temperature as well. Color changes could be due to oxidation of red oxymyoglobin into brown metmyoglobin (Wood et al. 2004).

Total Viable Count (TVC): The present study indicated that the incorporation of different types of fats showed significant results $(P \leq 0.05)$ described precisely in the 
table (2). PKBF sausages showed lowest TVC values represented in terms of $\log \mathrm{cfu} / \mathrm{g}$ whilst highest values were observed in STF sausages; however, KPH sausages showed mediate values. Moreover, a positive correlation between the $\log \mathrm{cfu} / \mathrm{g}$ values and $\mathrm{mg} / \mathrm{kg}$ malonaldehyde values has been truly reported in the literature (Sahoo and Anjaneyulu 1997). Evaluation criteria of shelf life were decided on the basis of TBARS and TVC of the sausages, showed that refrigerated samples reached their maximum acceptable limit on $11^{\text {th }}$ day. In contrast, ambient temperature stored sausages reached threshold limits on $5^{\text {th }}$ day explained clearly in figure (1).

Results demonstrated that $\log \mathrm{cfu} / \mathrm{g}$ values of sausages increased significantly with the increase in storage duration. Findings were in accordance with the results of (Ahmad and Srivastava,2007), who found a linear increase in TPC values with the progress in the refrigerated storage period. Sachindra et al. (2005) determined the exponential increase in $\log \mathrm{cfu} / \mathrm{g}$ values from an initial count of $4.08 \pm 1$ to $6.53 \pm 0.17$ during a storage period of $0-16$ days.

In the current study, it was found that with the rise in storage temperature, TVC values of sausages were considerably increased, showing the direct correlation. Sausages placed at $34^{\circ} \mathrm{C}$ provided more optimal conditions for bacterial multiplication than sausages placed at $2{ }^{\circ} \mathrm{C}$. Kandeepan et al. (2006) showed similar trends elaborating total plate count of buffalo meat mince stored at ambient temperature was significantly $(P \leq$ $0.01)$ higher than meat mince placed at refrigeration storage. Furthermore, it had been reported that aerobic mesophilic bacterial count and growth was markedly increased at higher temperatures (Narasimha and Ramesh 1988). Likewise, aerobic bacterial counts enumerated were significantly $(P \leq 0.05)$ higher for $34^{\circ} \mathrm{C}$ treatments compared to $16^{\circ} \mathrm{C}$ and $27^{\circ} \mathrm{C}$ degree treatments (Thomas et al. 2007). When the total viable count of meat products exceeds above $\log 10^{7} / \mathrm{g}$, then that specific product could be declared as unfit for human consumption (Verma and Sahoo 2000).

Thiobarbituric acid reactive substances (TBARS): Means and standards errors of TBARS are presented in table (2). In the present study, significantly $(P \leq 0.05)$ higher TBARS values were observed in sausages prepared from STF and stored at $35 \pm 2{ }^{\circ} \mathrm{C}$. STF sausages exhibited greater TBARS values whilst the lowest values were detected in PKBF sausages, whereas KPH sausages showed intermediate values. Furthermore, STF sausages were more prone to lipid oxidation represented in table (2). It was associated with the amount of total unsaturated fatty acids (USFA) present (Dzudie et al. 2005). The order of unsaturation in fats was $\mathrm{STF}>\mathrm{KPH}>\mathrm{PKBF}$. Similarly, Aksu (2009) reported that sheep tail fat has more unsaturated fatty acids than beef kidney fat. Unsaturated fatty acids with double, multiple bonds tend to oxidize at a higher pace, and lipid oxidation could be accelerated (Wood et al. 2004).

Storage duration had a significant effect $(P \leq$ $0.05)$ on lipid oxidation in KPH sausages. These facts correlated with Naveena and Kiran (2014) findings, who found that TBA values of duck meat sausages increased significantly as storage progressed to 14 days. Increment in TBA values might be attributed due to the oxidation of fatty acids during storage duration. Similarly, it was observed that overall TBA values increased periodically in samples over time (Iheagwara and Okonkwo, 2016). Similarly, Rubio et al. (2008) found that TBARS were increased exponentially until the $10^{\text {th }}$ day of storage.

Lower TBARS values were recorded for samples stored at chilling temperature $\left(2 \pm 2{ }^{\circ} \mathrm{C}\right)$ as compared to samples placed at ambient temperature (35 \pm $2{ }^{\circ} \mathrm{C}$ ). Moreover, the same trend was observed between types of storage at $5^{\circ} \mathrm{C}$ and $15^{\circ} \mathrm{C}$ by Kamenik, (2012). Lipid oxidation was markedly affected by storage temperature because the maximum number of free radicals were detected from meat products placed at higher temperatures (Ladikos and Lougovois, 1990). However, excluding samples stored at $35 \pm 2^{\circ} \mathrm{C}$ for more than seven days of the storage, the TBARS values of remaining samples were within the acceptable range of the $1-2 \mathrm{mg} / \mathrm{kg}$ of malonaldehyde that was minimum detectable level for oxidized flavor in beef and beef products (Greene and Cumuze, 1982). This might be due to the addition of antioxidant ascorbic acid, phosphates and spraying 5\% potassium ascorbate that would have retarded lipid oxidation.

Water Activity (a $\left.\mathbf{a}_{\mathbf{w}}\right)$ : Statistically significant results $(P \leq$ $0.05)$ were obtained depicted in the table (2). STF and KPH fat incorporation resulted in slightly higher $a_{w}$ values than that of PKBF fat-based sausages. Contrarily, Lengkey and Lobo (2016) reported the lowest $\mathrm{a}_{\mathrm{w}}$ in native chicken and rabbit sausages where corn oil was used, while highest values were noted in beef fat sausages. Moreover, sausages having lower $\mathrm{a}_{\mathrm{w}}$ have better microbial stability. Statistically significant $(P \leq 0.05)$ results in accounting storage duration and storage temperature. For ambient temperature $\left(35 \pm 2^{\circ} \mathrm{C}\right)$ stored samples, $\mathrm{a}_{\mathrm{w}}$ values were slightly higher than that of the samples that were stored at chilling temperature $\left(2 \pm 2^{\circ} \mathrm{C}\right)$.

Drip loss, chilling loss and moisture loss due to evaporation could be the main reason behind the reduction in $\mathrm{a}_{\mathrm{w}}$ values in samples stored at $2 \pm 2^{\circ} \mathrm{C}$. Evaporative losses or dehydration causes a decline in the $\mathrm{a}_{\mathrm{w}}$ values of samples placed at $35 \pm 2^{\circ} \mathrm{C}$. These results of the present study are in line with the findings of Arief et al. (1989), who determined moisture content of buffalo meat decreased with the advancement in chilled and frozen storage, resulting in moisture losses due to evaporation of moisture from the meat. With the advancement of storage days, the water activity of sausages was slightly increased. These findings were in line with the study of Andres et al. 
(2006) that $\mathrm{a}_{\mathrm{w}}$ of chicken meat sausages decreased during the 28-days storage.

Sausages are popular meat products having a variety of recipes and nutritional profile. Enhancement of shelf life of meat products is always a favorite research topic for a food scientist. Fat supplementation effect on chemical and microbial shelf life studied in this study. Results show that sausages made from palm kernel butterfat had the highest shelf life as compared to the animal source fat sources. These results also satisfy the ethnic requirement of the Pakistani population.

Table 1. Influence of different fat sources, storage temperature and storage duration on CIE Instrumental CIE color attributes of cooked beef sausages.

\begin{tabular}{|c|c|c|c|c|c|c|}
\hline $\begin{array}{c}\text { Fat } \\
\text { Source }\end{array}$ & $\begin{array}{c}\text { Storage } \\
\text { Temp }\end{array}$ & $\begin{array}{c}\text { Storage } \\
\text { Duration } \\
\text { (day) }\end{array}$ & $\mathrm{L}^{*}$ & $a^{*}$ & $b^{*}$ & $\mathrm{c}$ \\
\hline \multirow{11}{*}{$\mathrm{KPH}$ fat } & \multirow{6}{*}{$2^{\circ} \mathrm{C}$} & 1 & $52.86^{\mathrm{c}} \pm 0.05$ & $17.83^{\mathrm{op}_{ \pm}} 0.02$ & $10.81^{\mathrm{de}_{ \pm}} \pm 0.04$ & $20.85^{1} \pm 0.00$ \\
\hline & & 3 & $51.78^{\mathrm{de}_{ \pm}} 0.01$ & $17.91^{\circ} \pm 0.02$ & $10.69^{\mathrm{fg}} \pm 0.00$ & $20.86^{1} \pm 0.01$ \\
\hline & & 5 & $51.57^{\mathrm{def}_{ \pm}} \pm 0.05$ & $18.72^{\mathrm{kl}} \pm 0.00$ & $10.62^{\mathrm{ghi}_{ \pm}} \pm 0.03$ & $21.52^{\mathrm{g}} \pm 0.01$ \\
\hline & & 7 & $50.99^{\mathrm{fgh}} \pm 0.02$ & $18.84^{\mathrm{hijk}} \pm 0.01$ & $10.43^{\mathrm{jk}} \pm 0.04$ & $21.53^{\mathrm{g}} \pm 0.02$ \\
\hline & & 9 & $50.48^{\mathrm{hij}_{ \pm}} 0.09$ & $18.95^{\mathrm{efgh}} \pm 0.04$ & $10.28^{1} \pm 0.04$ & $21.55^{\mathrm{fg}_{ \pm}}{ }_{0.05}$ \\
\hline & & 11 & $50.09^{\mathrm{ij}} \pm 0.04$ & $19.17^{\mathrm{c}} \pm 0.03$ & $10.22^{\operatorname{lm}_{ \pm}} 0.05$ & $21.72^{\mathrm{de}_{ \pm}} \pm 0.00$ \\
\hline & \multirow{4}{*}{$35^{\circ} \mathrm{C}$} & 1 & $52.74^{\mathrm{c}} \pm 0.36$ & $18.60^{\mathrm{mn}} \pm 0.01$ & $11.85^{\mathrm{a}} \pm 0.04$ & $22.05^{\mathrm{b}} \pm 0.02$ \\
\hline & & 3 & $51.41^{\mathrm{def}_{ \pm}} 0.20$ & $18.79^{\mathrm{ijk}} \pm 0.03$ & $11.01^{\mathrm{c}} \pm 0.02$ & $21.78^{\mathrm{cd}_{ \pm}} 0.01$ \\
\hline & & 5 & $50.41^{\mathrm{hij}_{ \pm}} .33$ & $19.18^{c} \pm 0.01$ & $10.50^{\mathrm{ij}} \pm 0.05$ & $21.87^{\mathrm{c}} \pm 0.03$ \\
\hline & & 7 & $49.39^{\mathrm{kl}} \pm 0.07$ & $19.69^{b} \pm 0.04$ & $10.13^{\mathrm{mn}} \pm 0.02$ & $22.14^{\mathrm{a}} \pm 0.03$ \\
\hline & \multirow{6}{*}{$2^{\circ} \mathrm{C}$} & 1 & $54.76^{\mathrm{a}} \pm 0.02$ & $17.28^{\mathrm{q}} \pm 0.01$ & $11.15^{\mathrm{b}} \pm 0.05$ & $20.56^{\mathrm{m}} \pm 0.02$ \\
\hline \multirow{9}{*}{$\begin{array}{c}\text { Palm } \\
\text { Kernel } \\
\text { Butter } \\
\text { Fat }\end{array}$} & & 3 & $54.54^{\mathrm{a}} \pm 0.02$ & $18.48^{\mathrm{n}} \pm 0.01$ & $10.74^{\mathrm{efg}} \pm 0.04$ & $21.37^{\mathrm{ijk}} \pm 0.03$ \\
\hline & & 5 & $53.63^{b} \pm 0.48$ & $18.59^{\mathrm{mn}} \pm 0.01$ & $10.44^{\mathrm{j}} \pm 0.02$ & $21.32^{\mathrm{jk}} \pm 0.01$ \\
\hline & & 7 & $53.68^{\mathrm{b}} \pm 0.29$ & $18.74^{\mathrm{jk}} \pm 0.03$ & $10.34^{\mathrm{kl}} \pm 0.00$ & $21.40^{\mathrm{hij}_{ \pm}} 0.03$ \\
\hline & & 9 & $52.94^{c} \pm 0.05$ & $18.98^{\mathrm{efg}_{ \pm}} 0.01$ & $10.24^{\mathrm{lm}_{ \pm}} 0.01$ & $21.56^{\mathrm{fg}_{ \pm}} 0.01$ \\
\hline & & 11 & $52.75^{\mathrm{c}} \pm 0.04$ & $19.12^{\mathrm{cd}} \pm 0.03$ & $10.13^{\mathrm{mn}} \pm 0.00$ & $21.63^{\mathrm{ef}_{ \pm}} 0.02$ \\
\hline & \multirow{4}{*}{$35^{\circ} \mathrm{C}$} & 1 & $51.84^{\mathrm{de}_{ \pm}} \pm 0.19$ & $18.53^{n} \pm 0.06$ & $10.88^{\mathrm{d}} \pm 0.02$ & $21.49^{\mathrm{gh}} \pm 0.06$ \\
\hline & & 3 & $51.55^{\mathrm{def}_{ \pm}} \pm 0.05$ & $18.86^{\mathrm{ghij}_{ \pm}} 0.02$ & $10.62^{\mathrm{ghi}_{ \pm}} \pm 0.05$ & $21.64^{\mathrm{ef}} \pm 0.04$ \\
\hline & & 5 & $51.25^{\mathrm{efg}_{ \pm}} .23$ & $19.12^{\mathrm{cd}} \pm 0.01$ & $10.44^{\mathrm{j}} \pm 0.03$ & $21.78^{\mathrm{cd}_{ \pm}} 0.01$ \\
\hline & & 7 & $49.89^{\mathrm{kj}_{ \pm}} 0.07$ & $19.81^{\mathrm{ab}} \pm 0.04$ & $10.06^{\mathrm{no}} \pm 0.04$ & $22.21^{\mathrm{a}} \pm 0.01$ \\
\hline \multirow{10}{*}{$\begin{array}{l}\text { Sheep } \\
\text { tail fat }\end{array}$} & \multirow{6}{*}{$2^{\circ} \mathrm{C}$} & 1 & $52.80^{c} \pm 0.08$ & $17.78^{\mathrm{p}} \pm 0.10$ & $10.78^{\mathrm{def}_{ \pm}} \pm 0.05$ & $20.79^{1} \pm 0.06$ \\
\hline & & 3 & $51.90^{\mathrm{d}} \pm 0.09$ & $18.67^{\mathrm{lm}_{ \pm}} 0.01$ & $10.64^{\mathrm{gh}} \pm 0.04$ & $21.49^{\mathrm{gh}} \pm 0.03$ \\
\hline & & 5 & $51.52^{\mathrm{def}_{ \pm}} \pm 0.02$ & $18.50^{\mathrm{n}} \pm 0.02$ & $10.51^{\mathrm{hij}_{ \pm} 0.01}$ & $21.28^{\mathrm{k}} \pm 0.02$ \\
\hline & & 7 & $50.94^{\mathrm{fgh}_{ \pm}} \pm .12$ & $18.73^{\mathrm{kl}} \pm 0.04$ & $10.48^{\mathrm{j}_{ \pm}} 0.00$ & $21.46^{\mathrm{ghi}_{ \pm}} \pm 0.03$ \\
\hline & & 9 & $50.57^{\mathrm{hi}_{ \pm}} \pm 0.08$ & $18.91^{\mathrm{fghi}} \pm 0.05$ & $10.26^{1} \pm 0.09$ & $21.51^{\mathrm{g}} \pm 0.00$ \\
\hline & & 11 & $50.26^{\mathrm{ij}} \pm 0.00$ & $19.04^{\mathrm{def}_{ \pm}} \pm 0.11$ & $10.09^{n} \pm 0.02$ & $21.54^{\mathrm{fg}_{ \pm}} 0.08$ \\
\hline & \multirow{4}{*}{$35^{\circ} \mathrm{C}$} & 1 & $53.36^{\mathrm{bc}} \pm 0.58$ & $18.57^{\mathrm{mn}} \pm 0.04$ & $10.84^{\mathrm{de}_{ \pm}} \pm 0.07$ & $21.50^{\mathrm{gh}} \pm 0.01$ \\
\hline & & 3 & $51.65^{\mathrm{de}_{ \pm}} \pm 0.04$ & $18.94^{\mathrm{efgh}} \pm 0.03$ & $10.56^{\mathrm{hij}_{ \pm}} 0.02$ & $21.68^{\mathrm{de}} \pm 0.02$ \\
\hline & & 5 & $50.71^{\mathrm{ghi}_{ \pm}} \pm 0.23$ & $19.06^{\mathrm{cde}} \pm 0.03$ & $10.48^{\mathrm{j}_{ \pm}} 0.01$ & $21.75^{\mathrm{d}} \pm 0.02$ \\
\hline & & 7 & $49.02^{1} \pm 0.01$ & $19.86^{\mathrm{a}} \pm 0.09$ & $9.95^{\circ} \pm 0.06$ & $22.21^{\mathrm{a}} \pm 0.05$ \\
\hline
\end{tabular}

Superscripts on different means within column differ significantly $(P \leq 0.05)$.

Table 2. Influence of buffalo KPH fat, palm kernel butter fat, sheep tail fat, storage time and temperature on TBARS, TVC and water activity of cooked beef sausages.

\begin{tabular}{|c|c|c|c|c|c|}
\hline $\begin{array}{c}\text { Fat } \\
\text { Source }\end{array}$ & $\begin{array}{c}\text { Storage } \\
\text { Temp }\left({ }^{\circ} \mathrm{C}\right)\end{array}$ & $\begin{array}{c}\text { Storage } \\
\text { Duration (Days) }\end{array}$ & $\begin{array}{c}\text { TBARs } \\
\text { (mg/kg } \\
\text { malonaldehyde) }\end{array}$ & $\begin{array}{c}\text { TVC } \\
(\log \mathrm{cfu} / \mathrm{g})\end{array}$ & Water Activity \\
\hline \multirow{5}{*}{$\mathrm{KPH}$ fat } & \multirow{5}{*}{2} & 1 & $0.25^{\mathrm{p}} \pm 0.01$ & $4.04^{\mathrm{pq}} \pm 0.00$ & $0.93^{i} \pm 0.00$ \\
\hline & & 3 & $0.62^{\mathrm{mn}} \pm 0.02$ & $4.24^{\mathrm{no}} \pm 0.24$ & $0.92^{\mathrm{d}} \pm 0.00$ \\
\hline & & 5 & $0.83^{1} \pm 0.01$ & $4.48^{\operatorname{lm}_{ \pm}} .0 .01$ & $0.92^{\mathrm{e}} \pm 0.00$ \\
\hline & & 7 & $1.15^{\mathrm{ij}} \pm 0.03$ & $4.90^{\mathrm{hi}_{ \pm}} 0.01$ & $0.92^{\circ} \pm 0.00$ \\
\hline & & 9 & $1.41^{\mathrm{fg}} \pm 0.02$ & $6.41^{c} \pm 0.00$ & $0.91^{\mathrm{hi}_{ \pm} 0.00}$ \\
\hline
\end{tabular}




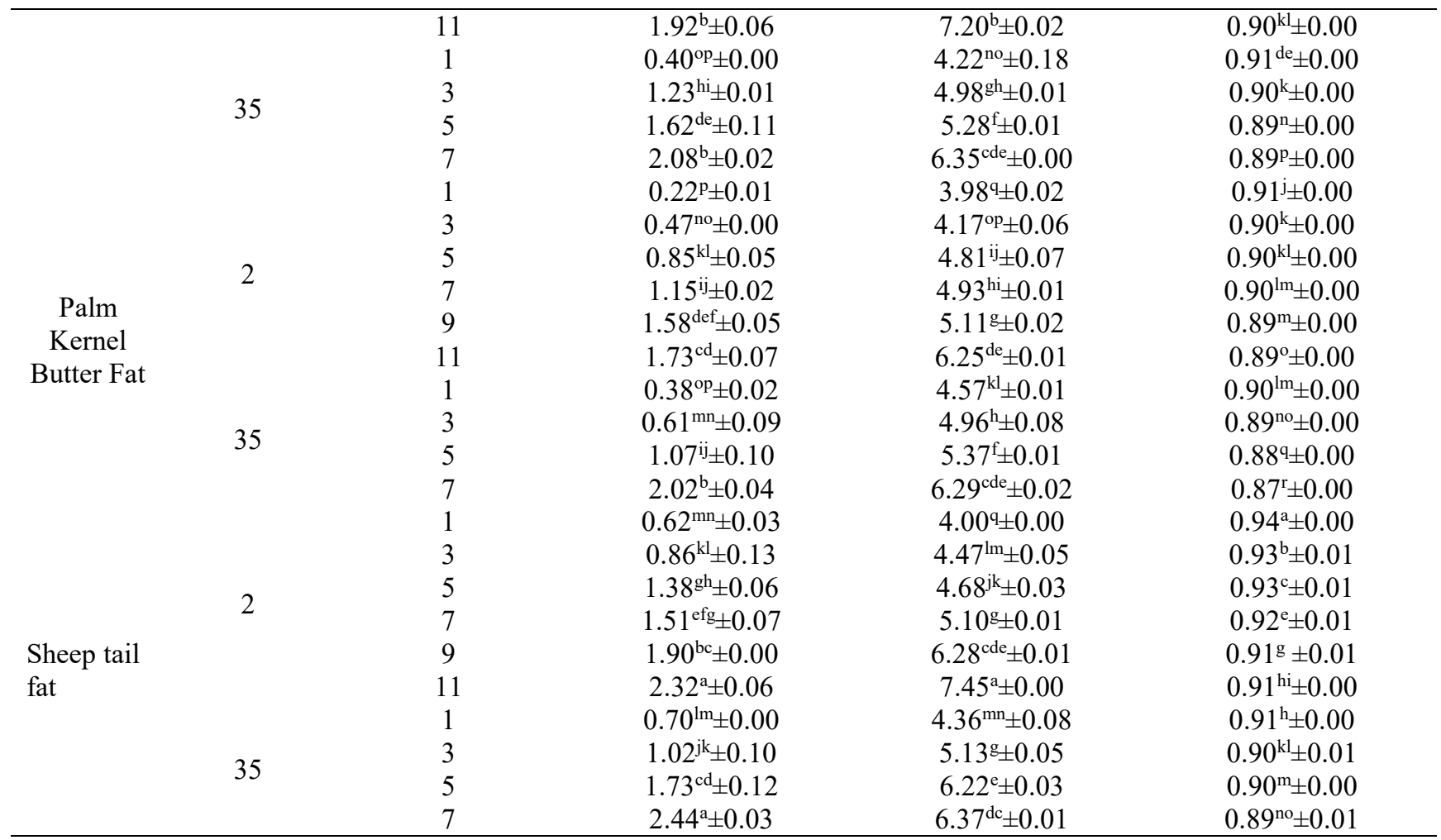

Conclusions: It was noted that palm kernel butter fat sausages exhibited marginally lower TVC and TBARS as compared to the KPH and sheep tail fat sausages. Furthermore, sausages were shelf-stable up to $7^{\text {th }}$ day at ambient temperature $\left(35 \pm 2{ }^{\circ} \mathrm{C}\right)$, whereas the sausages that were placed at $2 \pm 2^{\circ} \mathrm{C}$ remain shelf-stable up to $10^{\text {th }}$ day of storage. Moreover, storage time and temperature showed a positive linear relationship with the TVC and TBARS, representing a parallel increase in storage duration and temperature. Utilization of palm kernel butterfat source stored at refrigerated temperature was recommended, followed by KPH and sheep tail fat.

\section{REFERENCES}

Ahmad, S., and P. K. Srivastava (2007). Quality and shelf-life evaluation of fermented sausages of buffalo meat with different levels of heart and fat. Meat. Sci. 75(4): 603-609.

Aksu, M.I (2009). Fatty acid composition of beef intermuscular, sheep tail, beef kidney fats and its effects on shelf life and quality properties of kavurma. J. Food. Sci. 74(2): 65-72.

American Public Health Association (APHA) (1992). Standard Methods for Examination of Water and waste 18th ed. American Public Health Association, Washington D.C.

Andres, S.C., N.E. Zaritzky, and A.N. Califano (2006). The effect of whey protein concentrates and hydrocolloids on the texture and color characteristics of chicken salami. Int. J. Food. Sci. Technol. 41(2): 954-961.

Arief, M.A., K.P. Reddy, and V.R.Reddy (1989). Influence of packaging (wrapping) materials and storage periods on certain chemical and organoleptic characteristics of broiler cut up parts. Kerala. J. Vet. Sci. 20: 107-114.

Borghese, A. (2005). Buffalo meat and meat industry. In Buffalo Production and Research (ed. A Borghese), pp. 197-217. Food and Agriculture Organization of the United Nations, Rome, Italy.

Brooks JD, Flint SH (2008). Biofilms in the food industry: problems and potential solutions. Int. J. Food Sci. Technol. 43(12): 2163-2176.

Cáceres, E., M.L. García, and M.D. Selgas (2008). Effect of pre-emulsified fish oil - as source of PUFA n-3 - on microstructure and sensory properties of mortadella, a Spanish bologna-type sausage. Meat. Sci. 80(2): 183-193.

Cavalheiro, C.P., N. Piovesan, L.D.M. Terra, M. Lovato, N.N. Terra, and L.L.M. Fries (2013). Colorimetric and sensory characteristics of fermented cured sausage with Brazilian ostrich meat addition. Food.Sci. Technol. 33(4): 660665.

Das, H., and K. Radhakrishna (2001). Preservation of mutton as ready-to eat curry by hurdle technology. J. Food Sci. Technol.38(3): 287289. 
Dzudie, T., J. Scher, C. Tchiegang, and J. Hardy (2005). Effect of fat sources on the physico-chemical nutritional and textural properties of beef sausages. J. Food. Technol. 3(2):220-225.

Greene, B.E., and T.H.Cumuze (1982). Relationship between the TBA numbers and in-experienced panelists assessments of oxidized flavour in cooked beef. J. Food. Sci. 47(1): 52-54.

Guo, H. L., D. C. Liu, and M. T.Chen (2003). Color stability of Chinese-style sausage inoculated with Staphylococcus carnosus and Staphylococcus xylosus. Asian-Aust. J. Anim. Sci. 16(4): 570-574.

Górska-Warsewicz, H., W. Laskowski, O. Kulykovets, A. Kudlińska-Chylak, M. Czeczotko, and K. Rejman (2018). Food products as sources of protein and amino acids-the case of Poland. Nutrients, 10(12), 1-20.

Iheagwara, M.C., and T.M. Okonkwo (2016). Influence of storage duration on stability and sensorial quality of dried beef product (Kilishi). J. Food. Process. Technol. 7(4): 574-578.

Kamenik, J., A.Salakova, G. Borilova, Z. Pavlik, E. Standarova, and L. Steinhauser (2012). Effect of storage temperature on the quality of dry fermented sausage Polican. Czech. J. Food. Sci. 30(4): 293-301.

Kanatt, S.R., S.P. Chawla, R. Chander, and D.R. Bongirwar (2002). Shelf-stable and safe intermediate moisture meat products using hurdle technology. J. Food Prot. 65(10): 16281631.

Kandeepan, G., S. Biswas, and K. Porteen (2006). Influence of histological changes of refrigerator preserved buffalo meat on quality characteristics. J. Food. Technol. 4(2): 116-121.

Karthikeyan, J., S. Kumar, A.S.R. Anjaneyulu, and K.H. Rao (2000). Application of hurdle technology for the development of caprine keema and its stability at ambient temperature. Meat. Sci. 54(1): 9-15.

Ladikos, D., and V. Lougovois (1990). Lipid oxidation in muscle foods: A review. Food Chem. 35(4): 295-314.

Leistner, L (2000). Basic aspects of food preservation by hurdle technology. Int. J. Food. Microbiol. 55(1): 181-186.

Leistner, L., and L.G.M. Gorris (1995). Food preservation by hurdle technology. Trends. Food. Sci. Technol. 6(2): 41-46. DOI: https://doi.org/10.1016/S0924-2244(00)88941-4

Lengkey, H.A. and B.R. Lobo (2016). Physico-chemical and microbiological characteristics, sensory quality and acceptability of native chicken and rabbit sausage produced with corn oil, margarine and beef fat. Mac. Vet. Rev. 39(2): 193-199.
Lorenzo, J. M., R. M. González-Rodríguez, M. Sánchez, I. R. Amado, and D. Franco (2013). Effects of natural (grape seed and chestnut extract) and synthetic antioxidants (butylated hydroxytoluene, BHT) on the physical, chemical, microbiological and sensory characteristics of dry cured sausage "chorizo". Food. Res. Int. 54(1): 611-620.

Mielnik, M. B., E. Olsen, G. Vogt, D. AdelineandG. Skrede (2006). Grape seed extract as an antioxidant in cooked, cold-stored turkey meat. LWT - Food. Sci. Technol. 39(3): 191198.

Narasimha, R.D. and B.S. Ramesh (1988). Microbial profiles of minced meat. Meat. Sci. 23(4): 279291.

Nauman, K., P. Paulsen, F.J.M. Smulders (2016). Food safety and risk management of beef and beef products in Pakistan. Arch. Lebemittelhyg. 67(3):79-86.

Naveena, B.M., and M.Kiran (2014). Buffalo meat quality, composition, and processing characteristics: Contribution to the global economy and nutritional security. Anim. Front. 4(4): 18-24.

Ohkawa, H., N.Ohishi, and K.Yagi (1979). Assay for lipid peroxides in animal tissues by the thiobarbituric acid reaction. Anal. Biochem. 95(2): 351-358.

Qi, S., H. Huang, J. Huang, Q. Wang, and Q. Wei (2015). Lychee (Litchi chinensis Sonn.) seed water extract as potential antioxidant and anti-obese natural additive in meat products. Food. control. 50. 195-201.

Rubio, B., B. Martinez, M.D. Garcia-Cachan, J. Rovira, and I. Jaime (2008). Effect of the packaging method and the storage time on lipid oxidation and color stability on dry fermented salami salchichon manufactured with raw material with a high level of mono and polyunsaturated fatty acids. Meat. Sci. 80(2): 1182-1187.

Sachindra, N., P. Sakhare, K. Yashoda, and D.N. Rao (2005). Microbial profile of buffalo sausage during processing and storage. Food. control. 16(1): 31-35.

Sahoo, J., and A.S.R. Anjaneyulu (1997). Effect of natural antioxidants and vacuum packaging on the quality of buffalo meat nuggets during refrigerated storage. Meat. Sci. 47(4): 223-230.

Seo, J.K., H.W. Yum, G.D. Kim, J.Y. Jeong, and H.S. Yang (2016). Properties of frankfurter-type sausages with pork back-fat replaced with bovine heart surimi-like materials. Korean J Food Sci Anim Resour. 36(4): 523-30.

Tan, S., A. Aminah, S.A.Y. Mohd, O. Atil, and A.S. Babji (2001). Chemical, physical and sensory properties of chicken frankfurters substituted 
with palm fats. Int. J. Food. Sci. Nutr. 52(1): 9198.

Thakur, S. and D.C. Saxena (2000). Formulation of extruded snack food (gum-based cereal-pulse blend): optimization of ingredients levels using response surface methodology. LWT - Food. Sci. Technol. 33(5):354-361.

Thomas, R., A. Anjaneyulu, and N. Kondaiah (2008). Development of shelf stable pork sausages using hurdle technology and their quality at ambient temperature $\left(37 \pm 1^{\circ} \mathrm{C}\right)$ storage. Meat. Sci. $79(1)$ : $1-12$.

Thomas, R., A.S.R. Anjaneyulu, Y.P. Gadekar, H. Pragati, and N. Kondaiah (2007). Effect of comminution temperature on the quality and shelf life of buffalo meat nuggets. Food. Chem. 103(3): 787-794.
Valin, C., A.Pinkas, H.Dragnev, S.Boikovski, and D. Polikronov (1984). Comparative study of buffalo meat and beef. Meat. Sci. 10(1): 69-84.

Verma, S.P., and J. Sahoo (2000). Improvement in the quality of ground chevon during refrigerated storage by tocopherol acetate pre-blending. Meat. Sci. 56(1): 403-413.

Wood, J.D., R.I.Richardson, G.R. Nute, A.V. Fisher, M.M. Campo, E. Kasapidou, P.R. Sheard, and M. Enser (2004). Effects of fatty acids on meat quality: a review. Meat. Sci. 66(1): 21-32.

Yang, H.S., S.G. Choi, J.T. Jeon, G.B. Park, and S.T. Joo (2007). Textural and sensory properties of lowfat pork sausages with added hydrated oatmeal and tofu as texture modifying agents. Meat. Sci. 75(2):283-28. 